\title{
アルキルアントラキノンからの分散染料
}

\section{(第 3 報)}

\author{
森 禎 良*・黒木宣彦* 小西謙 三*
}

Disperse Dyes from Alkylanthraquinones. III.

Sadayoshi Mori*, Nobuhiko Kuroki* and Kenzo Konishi*

\begin{abstract}
6-Methylquinizarin was synthesized through the Diels-Alder reaction of naphthazarin or 5,8-diacetoxy-1,4-naphthoquinone with isoprene. Disperse dyes were prepared from 6-methyl-quinizarin, and their dyeing properties on acetate and Tetoron examined. The $\lambda_{\max }$ of these dyes in ethyl alcohol shifts to shorter wave length than that of the corresponding 1,4-disubstituted anthraquinones. The colors of dyed cloth vary from violet to greenish blue. Their dyeabilities on Tetoron were as good as that of the corresponding 1,4-disubstituted anthraquinones. The light fastness on acetate was better but that on Tetoron was worse than that of the corresponding 1,4-disubstituted anthraquinones. Their wash fastness on acetate was good. The dyes which have bulky substituents or hydrophilic groups showed good :sublimation fastness on Tetoron.
\end{abstract}

\section{I. 緒言}

アントラ羊ノン系分散染料の中で $\beta$ 位にメチル基を持 った化合物は多数合成されているが，これらのほとんど が 1-アミク -2-メチルアントラキクン (C. I. Disperse Orange 11)のようにアミノ基とメチル基がアントラキ ノンの同じベンゼン環に入った化合物である。一方アミ ク基とメチル基がアントラキノンの別々のベンゼン環に 入った化合物の含成例は少なく分散染料としてはわずか 著者らが報告1 した 1,4-ジ置換-6,7-ジメチルアントラ キノンがあるのみである。これら 1,4-ジ置換-6,7-ジメ チルアントラキノン系染料のアセテート，テトロンに対

* 大阪府立大学工学部応用化学科 (大阪府堺市百舌鳥 梅町)

* Department of Applied Chemistry, Callege of Engineering, University of Osaka Prefecture; (Mozu, Ume-machi, Sakai-shi, Osaka.)
する染色性は 1,4-ジ置換アントラキノン系染料にくら べより日光堅ロウ（アセテート上で），せんたく堅ロウ (アセテート上で), 昇華堅ロウ（テトロン上で）あっ た。そこで本研究では一連の 1,4 -ジ置換-6-メチルアン トラキノン系分散染料を合成してそれらのアセテート, テトロンに対する染色性を検討した。染料中間体の一つ である 6-メチルキニザリン (5) は Niementonski ${ }^{2}$ が 4-メチル無水フタル酸とヒドロキノンを縮合して合成し ているが，もら一つの方法として考えられるナフタザリ ンとイソプレンの Diels-Alder 反応からの合成例はみあ たらない。ただ Dielerle ${ }^{3)}$ はジアセトキシナフトキノン とイソプレンの Diels-Alder 反応で 1,4-ジアセトキシー 5, 8, 9', 10'-テトラヒドロ-6-メチルアントラキ/ン (1) を合成し，これを加水分解して $5,6,7,8$-テトラヒドロー 6-メチルキニザリン（2）をえたと報告している。そこで 著者らは先ず Dielerle の文献に従ってジアセトキシナフ トキノンにイソプレンを付加させ (1) を合成しついで加 
水分解して (2) を合成した。<smiles>CC(C)C(C)C(C)C</smiles>

(1)

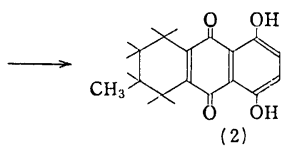

次に著者らは, 化合物 (2) を前報 ${ }^{1) の ~ 6,7-シ ゙ メ チ ル キ ~}$ ニザリンの合成法にならって,まずアセチル化して 1,4ジアセトキシ-5, 6, 7,8-テトラヒドロ-6-メチルアントラ キノン (3) を合成した。この化合物 (3) を無水クロム酸 で酸化して 1,4-ジアセトキシー6-メチルアントラキノン （4）をえ，ついで加水分解して目的の 6-メチルキニザ リン（5）を合成した。

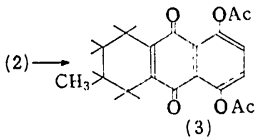<smiles>COc1ccc(OC)c2c1C(=O)c1ccc(Cl)cc1C2=O</smiles><smiles>O=C1c2ccccc2C(=O)c2c(O)ccc(O)c21</smiles>

また著者らは，ナフタザリンにイソプレンを DielsAlder 反応させて，5，8,9',10'-テトラヒドロ-6-メチル キニザリン（6）を合成した。この化合物（6）を水酸化ナ トリウム水溶液中で，しばらくかきまぜると青色溶液が えられるが，この溶液を塩酸々性にすると赤色沈殿が析 出した。この赤色沈殿が化合物 (1) の加水分解でえた化 合物 (2) と同じものであることを混融試験ならびに IR スペクトルから知ったので，水酸化ナトリウム水溶液中 で化合物（6）の $9^{\prime}, 10^{\prime}$ 位の水素原子は 6,7 位へ転位す ることがわかった。また化合物 (6) を $5 \%$ 水酸化ナトリ ウム水溶液中で空気を吹き込みながら煮沸すると 6-メ チルキニザリン（5）を一段階で合成することができた。<smiles>C=C(C)C(C)C</smiles><smiles>CC1=CC(C)(C)C2(C(C)(C)C)C(=O)c3c(O)c(O)cc(O)c3C(=O)C12</smiles>

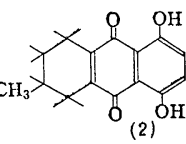<smiles>Cc1ccc2c(c1)C(=O)c1c(O)ccc(O)c1C2=O</smiles>

図 1 に化合物 (2)，化合物（5)，ナフタザリンキ二 ザシンのエタノール溶液での紫外線吸収スペクトルを示 したが化合物（2）がナフタザリン環を，また化合物 (5)

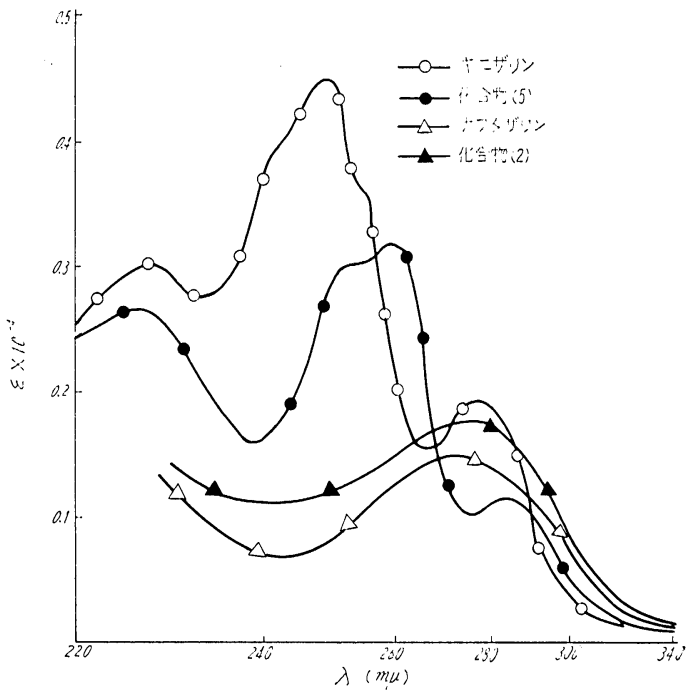

図 1

がキニザリン環を持っていることがわかる。

以上合成した中間体から染料を合成するのであるが， 1,4-ジアミノ置換-6-メチルアントラキノンの 合成には 6-メチルキニザリン（5）のロイコ体 (7) にアミンを反応 させるのが常法と考えられる。

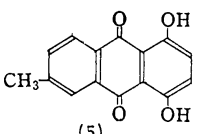

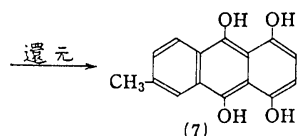

(7) $\mathrm{OH} \mathrm{OH}$<smiles></smiles>

しかし著者らは，ナフタザリンとイソプレンの付加物 （6）にアルキルアミンを反応させると,簡単に 1,4-ジア ルキルアミノ置換-6-メチルアントラキノンが生成する ことを知ったので，この方法によっても染料を合成し た。しかしアニリンは反応しなかった。

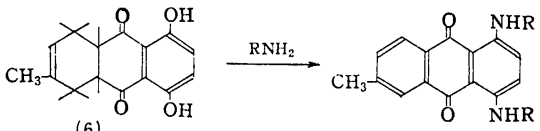

前報1で報告したように，ナフタザリンと 2 , 3-ジメチ ルブタジエンの付加物にアルキルアミンを反忍させた時 も同じように 1,4-ジアルキルアミノ置換-6,7-ジメチル アントラキノンを合成することができたが，このことか. 
ら考えてもこれら付加物にアミンが反応するのは，付加 物が次のような共鳴構造をとるためと考えられる。

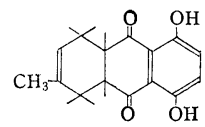

(6)

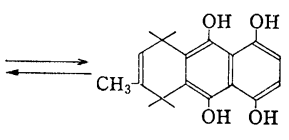

それぞれの染料の合成については以下に述べる。合成 した染料 $\left(1^{\prime}\right) \sim\left(9^{\prime}\right)$ は表 1 にまとめた。

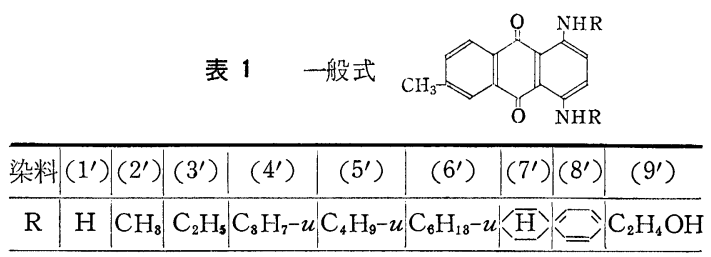

染料 $\left(1^{\prime}\right),\left(8^{\prime}\right),\left(9^{\prime}\right)$ は 6-メチルキニザリン (5)の口 イコ体 (7) にそれぞれアンモニア水溶液, アニリン, エ タノールアミンを反応させ，ついでニトロベンゼンーピ ペリジンで酸化して合成した。染料 $\left(2^{\prime}\right)$ も常法通りに ロイコ体 (7) にメチルアミン水溶液を反応させ, ついで 酸化して合成したがまた別に付加物 (6) にメチルアミン 水溶液を反応させると，アセトンに赤紫色に溶解する黒 色沈殿がえられたので，この沈殿をアルカリ水溶液中で 空気酸化したところ，常法で合成した染料 $\left(2^{\prime}\right)$ と同一 の化合物 (混融試験ならびに IR スペクトルから確認) をえた。すなわち染料 (2') は付加物 (6) からも合成で きることがわかった。この方法によって付加物 (6) にエ チルアミン水溶液を反応させて染料 $\left(3^{\prime}\right)$ を合成した。 染料 (5') は常法通りにロイコ体 (7) に n-ブチルアミン を反応させ，ついで酸化して合成したが一方付加物 (6) に $n$-ブチルアミンを反応させると溶媒中に青色針状結 晶が析出したが，この結晶は常法で合成した染料 (5') 上融点, IR スペクトルが一致したので染料 $\left(5^{\prime}\right)$ は付加 物 (6) からも直接合成できることがわかった。この反応 によって染料 $\left(4^{\prime}\right),\left(6^{\prime}\right),\left(7^{\prime}\right)$ を付加物 (6) と $n$-プロピ ルアミン，n-ヘキシルアミン，シクロヘキシルアミンか ら合成した。これらの染料 $\left(1^{\prime}\right) \sim\left(8^{\prime}\right)$ の精製にはベンゼ ン溶出アルミナカラムクロマト法 $\left.{ }^{4}\right)$ を用いた。染料 $\left(9^{\prime}\right)$ はクロルベンゼンから再結晶した。

\section{II. 実験}

1. 1,4-ジアセトキシナフトキノンの合成 ナフタ ザリン $10 \mathrm{~g}$ を無水酢酸 $80 \mathrm{~g}$ に分散した中へ濃硫酸 $1 \mathrm{~g}$ を加え $80^{\circ} \mathrm{C}$ で $30 \mathrm{~min}$ かきまぜた。冷後析出結晶を口 過して黄色結晶 (mp $174^{\circ} \sim 182^{\circ} \mathrm{C}$ ) $10.1 \mathrm{~g}$ をえた。酢酸 から再結晶した。 $\mathrm{mp} 186^{\circ} \sim 190^{\circ} \mathrm{C}$ (文献值 ${ }^{5)} \mathrm{mp} 189^{\circ} \sim$ $190^{\circ} \mathrm{C}$ )。

2. 1,4-ジアセトキシ-5, 8, 9', 10'-テトラヒドロ-6-メ チルアントラキノン (1) の合成＼cjkstart文献永にしたがって 1,4-ジアセトキシナフトキノン $8.7 \mathrm{~g}$, イソプレン $25 \mathrm{~g}$, エタノール $200 \mathrm{ml}$ をオートクレーブに大れ $100^{\circ} \mathrm{C} て ゙$ $8 \mathrm{hr}$ 振とうした。冷後口過して白色結晶 (mp 151〜 $\left.152^{\circ} \mathrm{C}\right) 8.2 \mathrm{~g}$ をえた。

3. $5,8,9^{\prime}, 10^{\prime}$-テトラヒドロ-6-メチルキニザリン (6) の合成 ナフタザリン $10 \mathrm{~g}$ ，イソプレン $25 \mathrm{~g}$ ，エ タノール $100 \mathrm{ml}$ をオートクレーブに入れ $110^{\circ} \mathrm{C}$ で $8 \mathrm{hr}$ 振とうした。冷後口過して淡黄色針状結晶 (mp 126〜 $\left.130^{\circ} \mathrm{C}\right) 9.5 \mathrm{~g}$ をえた。エタノールから二回再結晶して淡 黄色針状結晶 $\left(\mathrm{mp} \mathrm{131} \sim 133^{\circ} \mathrm{C}\right) 5.2 \mathrm{~g}$ をえた。元素分析 結果; found C: $69.38 \% \mathrm{H}: 5.21 \%$, cal. C: $69.77 \%$ $\mathrm{H}: 5.43 \%$ 。

4. 5, 6, 7, 8-テトラヒドロ-6-メチル キニザリン (2) の合成 文献 ${ }^{3}$ にしたがって付加物 (1) $2 \mathrm{~g}$ を $10 \%$ 水 酸化ナトリウム水溶液 $50 \mathrm{ml}$ に入れ室温で $3 \mathrm{hr}$ かきま ぜた。生じた青色反応溶液を塩酸々性にして赤味紫色沈 殿 (mp 144 147 $\left.{ }^{\circ} \mathrm{C}\right) 1.6 \mathrm{~g}$ をえた。ベンゼンーメタノー

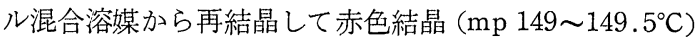
$1.3 \mathrm{~g}$ をえた(文献值 ${ }^{3)} \mathrm{mp} 151^{\circ} \mathrm{C}$ )。

別法 付加物 (6) $2 \mathrm{~g}$ を $5 \%$ 水酸化ナトリウム水溶液 $50 \mathrm{ml}$ に入れ $40 \sim 50^{\circ} \mathrm{C}$ で $3 \mathrm{hr}$ かきまぜた。生じた青 色反応溶液を塩酸々性にして赤味紫色沈殿 (mp 145 $\left.155^{\circ} \mathrm{C}\right) 1.5 \mathrm{~g}$ をえた。ベンゼンーメタノール混合溶媒か ら再結晶して赤カッ色結晶 $\left(\mathrm{mp} 150 \sim 151^{\circ} \mathrm{C}\right) 1.1 \mathrm{~g}$ をえ た。この結晶注付加物 (1) の加水分解でえた化合物 (2) と同一化合物であることを混融試験，IR スペクトルか ら確認した。IR 吸収スペクトル $(\mathrm{KBr}$ 法) $>\mathrm{C}=\mathrm{O} 1615$ $\mathrm{cm}^{-1}$ 。

5. 1, 4-ジアセトキシ-5, 6, 7, 8-テトラヒドロ-6-メチ ルアントラキノン (3) の合成 化合物 (2) $2 \mathrm{~g}$ を無水 酢酸 $14 \mathrm{ml}$ に入れ濃硫酸 5 滴を加えて $50^{\circ} \mathrm{C}$ で $2 \mathrm{hr}$ かき まぜた。冷後口過して析出淡黄色結晶 $\left(\mathrm{mp} \mathrm{184} 185^{\circ} \mathrm{C}\right)$ $2.4 \mathrm{~g}$ をえた。元素分析結果; found C: $66.49 \% \mathrm{H}$ : $5.15 \%$, cal. C: $66.67 \% \mathrm{H}: 5.26 \%$ 。

6. 1,4-ジアセトキシー6-メチルアントラキノン (4)の 合成 化合物 (3) $2 \mathrm{~g}$ 孛水酢酸 $16 \mathrm{ml}$ に入れ無水ク口 厶酸 $0.9 \mathrm{~g}$ を加えて $40^{\circ} \mathrm{C}$ で $5 \mathrm{hr}$ かきまぜた。冷後口 過して淡黄色結晶（mp 185 $\left.186^{\circ} \mathrm{C}\right) 1.7 \mathrm{~g}$ をえた。

7. 6-メチルキニザリン (5) の合成 化合物 (4) $1.5 \mathrm{~g}$ を $10 \%$ 水酸化ナトリウム水溶液 $50 \mathrm{ml}$ に入れ $30^{\circ} \mathrm{C}$ で $4 \mathrm{hr}$ かきまぜた。塩酸々性にしてから口過して だいだい色沈殿（mp 164〜 $165^{\circ} \mathrm{C}$ ) $1 \mathrm{~g}$ をえた（文献值 ${ }^{2}$ 
$\operatorname{mp~} 165^{\circ} \mathrm{C}$ )。

別法 付加物 (6) $2 \mathrm{~g}$ を $5 \%$ 水酸化ナトリウム水溶液 $50 \mathrm{ml}$ 中に分散させ空気を吹き込みながら $24 \mathrm{hr}$ 惹沸還 流した。椧後反応液を塩酸々性にしてから口過してだい だい色沈殿（mp 150〜 $157^{\circ} \mathrm{C}$ ) $1.5 \mathrm{~g}$ をえた。ベンゼンー メタノール混合溶媒から再結晶してだいだい色結晶 (mp 160〜162 ${ }^{\circ} \mathrm{C}$ ) をえた。この結晶が化合物 (4) の加水分解 でえた化合物 (5) と同一化合物であることを混融試験な らびに IR スペクトルより確認した。元素分析結果; found C: $70.99 \% \mathrm{H}: 3.81 \%$, cal. C: $70.87 \% \mathrm{H}$ : $3.94 \%$ 。IR 吸収スペクトル $(\mathrm{KBr}$ 法) $>\mathrm{C}=\mathrm{O} 1615$ $\mathrm{Cm}^{-1}$ 。

8. 6-メチルキニザリンのロイコ体 (7) の合成６メチルキニザリン (5) $\left(\mathrm{mp} 164 \sim 165^{\circ} \mathrm{C}\right) 1 \mathrm{~g}$ を水 $20 \mathrm{~m} l$, 無水炭酸ナトリウム $1 \mathrm{~g}$ の溶液に分散させ $80^{\circ} \mathrm{C}$ に加熱

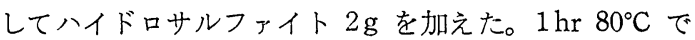
かきまぜてから熱時口過した。黄色沈殿（mp 130 $\left.132^{\circ} \mathrm{C}\right) 1 \mathrm{~g}$ をえた。

9. 1,4-ジアミノ-6-メチルアントラキノン (1') の合 成 ロイコ体 (7) $1 \mathrm{~g}$ を $28 \%$ アンモニア水溶液 $15 \mathrm{ml}$ に入れオートクレーブ中で $110^{\circ} \mathrm{C}$ で $7 \mathrm{hr}$ 振とうした。 冷後口過して黄カッ色結晶 (mp 232 234 ${ }^{\circ} \mathrm{C}$ ) $0.7 \mathrm{~g}$ を えた。この結晶 $0.7 \mathrm{~g}$ をニトロベンゼン $2 \mathrm{~m} l$ に入れピ リジン 3 滴を加えて $150^{\circ} \mathrm{C}$ で $15 \mathrm{~min}$ かきまぜた。冷後 口過して紫色結晶 (mp 230 232 $\left.{ }^{\circ} \mathrm{C}\right) 0.4 \mathrm{~g}$ をえた。力 ラムクロマトで精製して紫色針状結晶 (mp 232〜233ㄷ) をえた。 $\mathrm{N}$ 分析結果; found 10.8\%，cal. 11.0\%。

10. 1,4-ジメチルアミノ-6-メチルアントラキノン (2') の合成 ロイコ体 (7) $1 \mathrm{~g}$ を $30 \%$ メチルアミン 水溶液 $20 \mathrm{~m} l$ に入れ封管中 $85^{\circ} \mathrm{C}$ で $8 \mathrm{hr}$ かきまぜた。 冷後析出した黑色沈殿 (mp 176 180 $\left.{ }^{\circ} \mathrm{C}\right) 1 \mathrm{~g}$ をニトロベ ンゼンーピペリジンで酸化した後 水蒸気蒸留で溶媒を除 いて青色沈殿 (mp 174 180 $\mathrm{C}$ ) $1 \mathrm{~g}$ をえた。カラムクロ マトで精製して青色結晶（mp $213^{\circ} \sim 215^{\circ} \mathrm{C}$ ) をえた。 $\mathrm{N}$ 分析結果; found $9.78 \%$, cal. 10.0\%。

別法 付加物 (6) $1 \mathrm{~g}, 30 \%$ メルアミン水溶液 $15 \mathrm{~m} l$, ピリジン $3 \mathrm{ml}$ を $60 \sim 70^{\circ} \mathrm{C}$ で $10 \mathrm{hr}$ かきまぜ た。冷後水を加えてから口過して黒色沈殿 (mp 194 $\left.197^{\circ} \mathrm{C}\right) 0.9 \mathrm{~g}$ をえた。この沈殿はアセトンに赤紫色に溶 解したので染料の酸化体とロイコ体の混合と考えられ る。そこでこの沈殿 $0.9 \mathrm{~g}$ を $5 \%$ 水酸化カリウム水溶液 $20 \mathrm{~m} l$ 中に分散させ 空気を吹き込みながら $5 \mathrm{hr}$ 募沸還 流した。冷後口過して黑色沈殿 (mp 197 202 ${ }^{\circ} \mathrm{C}$ ) $0.9 \mathrm{~g}$ をえた。カラムクロマトで精製して青色結晶 (mp 214 $216^{\circ} \mathrm{C}$ ) をえた。この結晶はロイコ体（7）から合成した
（2'）と混融試験ならびに IR スペクほルの結果から同一 化合物であることを知った。IR 吸収スペクトル $(\mathrm{KBr}$

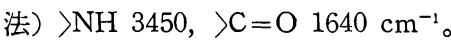

\section{1,4-シシェチルアミノ-6-メチルアントラキノン} (3') の合成 付加物 (6) $1 \mathrm{~g}, 70 \%$ エチルアミン水溶 液 $15 \mathrm{~m} l$ ，ピリジン $3 \mathrm{~m} l$ を $50^{\circ} \mathrm{C}$ で $7 \mathrm{hr}$ かきまぜた。 冷後析出した黒色針状結晶 $0.7 \mathrm{~g}$ を $5 \%$. 水酸化カリウ ム水溶液 $20 \mathrm{ml}$ 中に分散させ空気を吹き込みながら $5 \mathrm{hr}$ 煮沸還流した。冷後口過して青味黑色沈殿 (mp 197〜 $\left.205^{\circ} \mathrm{C}\right) 0.7 \mathrm{~g}$ をえた。カラムクロマトで精製して青色針 状結晶 (mp 207 208 ${ }^{\circ} \mathrm{C}$ ) をえた。 $\mathrm{N}$ 分析結果; found $8.92 \%$, cal. $9.09 \%$ 。

12. 1,4-ジ-n-プロピルアミノ-6-メチルアントラキ ノン (4') の合成 付加物 (6) $1.2 \mathrm{~g}, n$-プロピルアミ ン $10 \mathrm{~m} l$, ピリジン $5 \mathrm{~m} l$ を $50^{\circ} \mathrm{C}$ で $8 \mathrm{hr}$ さらに $70^{\circ} \mathrm{C}$ で 1hr かきまぜた。冷後析出した青色針状結晶（mp 148， $\left.\sim 150^{\circ} \mathrm{C}\right) 0.6 \mathrm{~g}$ をカラムクロマトで精製した。 $\mathrm{mp} \mathrm{150:}$ $\sim 152^{\circ} \mathrm{C}$ 。 $\mathrm{N}$ 分析結果; found $8.53 \%$, cal. $8.34 \%$ 。

13. 1,4-ジ-n-ブチル アミノ-6-メチル アントラキノ ン (5') の合成 ロイコ体 (7) $1 \mathrm{~g}, n$-ブチルアミン $5 \mathrm{~m} l$ を空気を窒素ガスとおきかえた封管中に入れ $85^{\circ} \mathrm{C}$. で $8 \mathrm{hr}$ かきまぜた。冷後希塩酸を加えた後口過して黒 色沈殿 (mp 135 137 ${ }^{\circ} \mathrm{C}$ ) $1.1 \mathrm{~g}$ をえた。ニトロベンゼ ンーピペリジンで酸化した後水蒸気蒸留で溶媒を除いて 青色沈殿 (mp 70 $85^{\circ} \mathrm{C}$ ) $1.1 \mathrm{~g}$ をえた。カラムクロマト で精製して青色針状結晶 ( $\left.\mathrm{mp} 97 \sim 98^{\circ} \mathrm{C}\right)$ をえた。 $\mathrm{N}$ 分 析結果; found $7.66 \%$, cal. $7.69 \%$ 。

別法 付加物 (6) $1.5 \mathrm{~g}, n$-ブチルアミン $15 \mathrm{ml}$, ピ. リジン $3 \mathrm{ml}$ を $85^{\circ} \mathrm{C}$ で $5 \mathrm{hr}$ かきまぜた。冷後希塩酸 を加えてから口過して青色沈殿 $\left(\mathrm{mp} 60 \sim 80^{\circ} \mathrm{C}\right) 1.9 \mathrm{~g}$ を えた。カラムクロマトで精製して青色針状結晶 (mp 97 〜98 $\mathrm{C}$ ) をえた。この結晶はロイコ体 (7) からえた染料 $\left(5^{\prime}\right)$ と同一化合物であることを混融試験，IR スペクト ルから確認した。IR 吸収スペクトル $(\mathrm{KBr}$ 法) > $\mathrm{NH}$ $3450,>\mathrm{C}=\mathrm{O} 1640 \mathrm{~cm}^{-1}$ 。

14. 1,4-ジ-n-ヘキシルアミノ-6-メチルアントラキ ノン $\left(\boldsymbol{6}^{\prime}\right)$ の合成 付加物 (6) $1.5 \mathrm{~g}, n$-ヘキシルアミ ン $10 \mathrm{~m} l$, ピリジン $1 \mathrm{~m} l$ を $100^{\circ} \mathrm{C}$ で $7 \mathrm{hr}$ かきまぜた。 冷後析出結晶を口過して青色針状結晶 (mp 98 $102^{\circ} \mathrm{C}$ ) $1.6 \mathrm{~g}$ をえた。カラムクロマトで精製して 青色針状結晶 (mp 104 105 ${ }^{\circ} \mathrm{C}$ ) をえた。 $\mathrm{N}$ 分析結果; found $6.51 \%$, cal $6.67 \%$ 。

15. 1,4-シシシクロヘキシルアミノ-6-メチルアントラ キノン ( $7^{\prime}$ ) の合成 付加物 (6) $1.5 \mathrm{~g}$; シクロヘキシ ルアミン $16 \mathrm{ml}$, ピリジン $3 \mathrm{ml}$ を $100^{\circ} \mathrm{C}$ で $10 \mathrm{hr}$ かき 
まぜた。冷後析出結晶をロ過して青色葉状結晶 (mp 223 〜225 $\left.{ }^{\circ} \mathrm{C}\right) 1.6 \mathrm{~g}$ をえた。カラムクロマトで精製して青色 針状結晶 (mp 224 225 $5^{\circ} \mathrm{C}$ )をえた。 $\mathrm{N}$ 分析結果; found $6.70 \%$, cal. $6.76 \%$ 。

16. 1,4-ジアニリン-6-メチルアントラキノン $\left(8^{\prime}\right)$ の

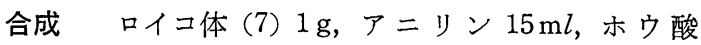
$0.5 \mathrm{~g}$ を $100 \sim 110^{\circ} \mathrm{C}$ で $5 \mathrm{hr}$ かきまぜた。冷後希塩酸 を加えしばらくかきまぜてから口過して紣色沈殿（mp $\left.120 \sim 125^{\circ} \mathrm{C}\right) 1.5 \mathrm{~g}$ をえた。この沈殿をニトロベンゼンー ピペリジンで酸化した後水蒸気蒸留で溶媒を除いて青味 黒色沈殿 $1.5 \mathrm{~g}$ をえた。カラムクロマトで精製して緑味 青色針状結晶（mp 193 194 $\left.{ }^{\circ} \mathrm{C}\right)$ をえた。 $\mathrm{N}$ 分析結果； found $6.95 \%$, cal. $6.93 \%$ 。

17. 1,4-ジェタノールアミノ-6-メチルアントラキノ ン $\left(\boldsymbol{9}^{\prime}\right)$ の合成 ロイコ体 (7) $1.5 \mathrm{~g}$, エタノールアミ ン $6 \mathrm{~m} l, n$-ブタノール $10 \mathrm{~m} l$ を $85^{\circ} \mathrm{C}$ で $7 \mathrm{hr}$ かきまぜ た。冷後口過して析出した 紺色結晶 (mp 190 195 ${ }^{\circ} \mathrm{C}$ ) $1 \mathrm{~g}$ をえた。クロルベンゼンから再結晶して青色結晶 (mp 199 202 ${ }^{\circ} \mathrm{C}$ ) をえた。N分析結果; found $8.10 \%$, cal. $8.19 \%$ 。

18. 染料 $\left(\mathbf{1}^{\prime}\right) \sim\left(\boldsymbol{8}^{\prime}\right)$ の精製法 $\left.{ }^{4}\right)$ 染料 $500 \mathrm{mg}$ を ベンゼン $200 \mathrm{~m} l$ にとかしてアルミナ $(200$ メッシュ) を高さ $15 \mathrm{~cm}$ につめた直径 $2.5 \mathrm{~cm}$ のガラス管に流し込 みさらに 200 $300 \mathrm{ml}$ のベンゼンを流してベンゼン溶液 を流出させた。この溶液を $10 \sim 20 \mathrm{ml}$ 亿濃縮して染料結 晶を析出させた。

\section{III. 染 色}

染色はアセテート拉よびテトロンについて行った。ア セテートは $1 \%$ 染め, 浴比 $1: 20$, 分散剂としてデモー ルNを布に対して $1 \%$ 用いて $85^{\circ} \mathrm{C} て ゙ ~ 1 \mathrm{hr}$ 染色した。 テトロンは高温染色機（田葉井製作所）を用いて染色し た。 $0.5 \%$ 染め, 浴比 $1: 50$, 分散剂にデモールNを $1 \%$ ，浸透剂ペレックス NB（花王石畧）を $0.5 \%$ 用い て $130^{\circ} \mathrm{C} て ゙ 1 \mathrm{hr}$ 染色した。染料の吸収極大值, 染色布 の色調を表 2 に示した。吸収極大值は日立分光々度計 EPU-2U 型を用いて約 $5 \times 10^{-4} \mathrm{~mol} / l$ のエタノール溶液 について室温で測定した。色調は日本色彩研究所 “色の 標蕉”（1954）にしたがった。染着性および各種堅ロウ 度試験結果を表 3 に示した。染着性の判定は 1,4-ジア ミノアントラキノンを標準にしてそれよりすぐれている ものを 5 , 同等のものを 4 , やや悪いものを 3 ，あまり 染着しないものを 2 として肉眼で視覚判定した。日光堅 ロウ度はフェードテスター（東洋理化工業 K.K.）を用 いて JIS K 4004 (1956)，まさつ堅口ウ度は学振型試験
表 2

\begin{tabular}{|c|c|c|c|c|c|}
\hline \multirow{2}{*}{ 染 料 } & \multicolumn{3}{|c|}{ 吸 収 極 大值 } & \multicolumn{2}{|c|}{ 染色布の色調 } \\
\hline & $\lambda_{\max } \mathrm{m} \mu$ & $\varepsilon_{\max }$ & $\times 10^{-4}$ & アセテート & テトロン \\
\hline$\left(1^{\prime}\right)$ & $552 \cdot 590$ & 0.732 & $\cdot 0.741$ & 柴 & 紫 \\
\hline$\left(2^{\prime}\right)$ & $592 \cdot 638$ & 1.59 & $\cdot 1.82$ & 明るい青 & 青 \\
\hline$\left(3^{\prime}\right)$ & $592 \cdot 638$ & 1.60 & $\cdot 1.84$ & 明るい青 & 青 \\
\hline$\left(4^{\prime}\right)$ & $592 \cdot 639$ & 1.64 & $\cdot 1.99$ & 明るい青 & 青 \\
\hline$\left(5^{\prime}\right)$ & $592 \cdot 639$ & 1.77 & $\cdot 2.23$ & 明るい青 & 青 \\
\hline$\left(6^{\prime}\right)$ & $592 \cdot 639$ & 1.67 & $\cdot 2.06$ & うす青 & 明るい青 \\
\hline$\left(7^{\prime}\right)$ & $592 \cdot 639$ & 1.75 & $\cdot 2.19$ & うす青 & うす青 \\
\hline$\left(8^{\prime}\right)$ & $595 \cdot 635$ & 1.14 & $\cdot 1.23$ & うす緑味青 & 緑味青 \\
\hline$\left(9^{\prime}\right)$ & $590 \cdot 635$ & 1.24 & $\cdot 1.14$ & こい青 & にぶ 青 \\
\hline
\end{tabular}

表 3

\begin{tabular}{|c|c|c|c|c|c|c|c|}
\hline \multirow{3}{*}{ 染。 } & \multirow{2}{*}{\multicolumn{2}{|c|}{ 染着 性 }} & \multicolumn{5}{|c|}{ 堅口ウ 度 (級) } \\
\hline & & & 日 & 光 & まさつ & 岁んた & 昇華 \\
\hline & $\begin{array}{l}\bar{\gamma} \text { ○テ } \\
\text { 一 }\end{array}$ & デトロ & 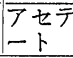 & Tテトロ & $\begin{array}{l}\text { 了セテ } \\
\text {-ト }\end{array}$ & 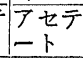 & $\overline{\bar{\sigma}}$ \\
\hline$\left(1^{\prime}\right)$ & 4 & 4 & $>6$ & 3 & 3 & 3 & 3 \\
\hline$\left(2^{\prime}\right)$ & 4 & 4 & 6 & 2 & 3 & $3-4$ & $2-3$ \\
\hline$\left(3^{\prime}\right)$ & 3 & 4 & $5-6$ & 2 & $3-4$ & 5 & 2 \\
\hline$\left(4^{\prime}\right)$ & 2 & 4 & 5 & 2 & 4 & 5 & 2 \\
\hline$\left(5^{\prime}\right)$ & 2 & 3 & 5 & 2 & 4 & 5 & 3 \\
\hline$\left(6^{\prime}\right)$ & 2 & 2 & 4 & 2 & 5 & 5 & $4-5$ \\
\hline$\left(7^{\prime}\right)$ & 2 & 2 & 3 & 3 & 3 & 5 & 5 \\
\hline$\left(8^{\prime}\right)$ & 2 & 2 & 3 & 3 & 3 & 5 & $4-5$ \\
\hline$\left(9^{\prime}\right)$ & 5 & 3 & $5-6$ & 2 & 3 & 4 & 5 \\
\hline
\end{tabular}

機を用いて JIS K 4009 (1956)，せんたく堅口ウ度は JIS K 4005 乙法 $\mathrm{H}-2$ 号 (1956), 昇華は $180^{\circ} \mathrm{C} \times 1 \mathrm{~min}$ でナイロン添布上の污染を判定した。

\section{IV. 結果}

1. 実験 4. および 7. 亿記述したように 5, 8, $9^{\prime}, 10^{\prime}$ テトラヒドロ-6-メチルキニザリン (6) の $9^{\prime}, 10^{\prime}$ 位の水 素原子はアルカリ水溶液中で 6,7 位へ転位することがわ かった。またこれら 5, 6,7,8 位の水素原子は熱アルカリ 水溶液中で空気酸化することによって容易に脱水素する ことがわかった。

2. 1,4-ジアミノ置換-6-メチルアントラキノンの合 成は 6-メチルキニザリンのロイコ体（7）にアミンを反 応させて行うのが常法であるが，アミンがアルキルアミ ンの場合にはナフタザリンとイソプレンの付加物 (6) に アミンを直接反応させて染料を合成することができた。 この方法によって染料 $\left(2^{\prime}\right),\left(3^{\prime}\right),\left(4^{\prime}\right),\left(5^{\prime}\right),\left(6^{\prime}\right),\left(7^{\prime}\right)$ を 収率よく合成した。

3. 融点を対応するメチル基のない1,4-ジ置換アン トラキノンとくらべるとほとんどの染料が低くなってい

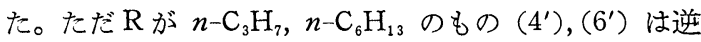


に高くなっていた。

4. エタノール溶液の吸収スペクトルは 1,4-ジアミ ノ置換アントラキノン類特有の double-headed peak を 示した。 $\lambda_{\max }$ は対応する染料よりすべて 短波長側に移 っていた。6位にメチル基を導入すると浅色効果になる ことがわかった。 $\mathrm{R}$ が $\mathrm{CH}_{3}$ より長いアルキル基になっ ても $\lambda_{\max }$ の位置が変化しないのは 1,4-ジアミノ置換ア ントラキノンの場合と同じである。

5. 染色布の色調は紫から緑味青であった。アセテー ト, テトロンに対する染着性は対応する染料と同程度で あった。アセテートに対しては $\mathrm{R}$ が $\mathrm{C}_{2} \mathrm{H}_{5}$ 以上長くなる と染着性が低下したがテトロンに対しては $\mathrm{R} か ゙ ~ n-\mathrm{C}_{3} \mathrm{H}_{7}$ でも標準程度の染着性を 示した。 $\mathrm{C}_{2} \mathrm{H}_{4} \mathrm{OH}$ 基を持った (9') はアセテートを濃色に染色した。

6. アセテート上の日光堅ロウ度は対忘する染料にく らべ若干堅ロウになっていた。しかしテトロンに対して は $2 \sim 3$ 級であった。

7. アセテート上でのまさつ堅ロウ度はアルキル基が 長くなるにしたがって若干堅ロウになっていた。

8. アセテート上でのせんたく堅ロウ度は $\mathrm{R}$ が $\mathrm{H}$, $\mathrm{CH}_{3}$ のもの $\left(1^{\prime}\right),\left(2^{\prime}\right)$ を除けばすべて 5 級とすぐれてい
た。

9. テトロン上での昇華堅ロウ度は $\mathrm{R}$ が $n \cdot \mathrm{C}_{6} \mathrm{H}_{13}$, $\langle\underline{\mathrm{H}}\rangle, \Longleftrightarrow, \mathrm{C}_{2} \mathrm{H}_{4} \mathrm{OH}$ のもの $\left(6^{\prime}\right),\left(7^{\prime}\right),\left(8^{\prime}\right),\left(9^{\prime}\right)$ は 45 〜5 級とすぐれていた。しかし対応するメチル基のない 1,4-ジアミノ置換アントラキノンとの差はみられなかっ た。

10. メチル基を 2 つ持った 1,4-ジアミノ㯰換-6,7-ジ メチルアントラキノン1 の対応するものとくらべてみる とアセテート上での日光堅口ウ度はすぐれていたが逆に テトロン上では悪くなっていた。またアセテート上での せんたく堅ロウ度およびテトロン上での昇華堅ロウ度も 良くなかった。

後記 本研究にあたり多くの便宜をあたえられた三菱 化成工業株式会社ならびに株式会社大東化学工業所に深 謝の意を示します。

\section{文献}

1) 森, 井上, 黒木, 小西, 有合化 23263 (1965)

2) Diementonski, Ber. 331634 (1900)

3) Dielerle, Ber. 642086 (1931)

4) 森, 黑木, 小西, 有合化 24683 (1966)

5) Wheeler, J. Am. Chem. Soc. 392465 (1917)

協会誌専用

\section{ファイルー}

協会誌専用の保存ファイルを準備しております。

ご希望の方は実費でお頒け致します故代金を添えてお忙迄み下さい。

定価 1 部 150 円 (12 冊綴り)

送料 1 部 70 円 